\title{
El pago voluntario de las multas en cuantía reducida; legalidad, eficacia, seguridad jurídica y tutela judicial efectiva
}

\author{
José $M^{a}$ Rodríguez de Santiago \\ Catedrático de Derecho Administrativo. Universidad Autónoma de Madrid \\ Josemaria.rodriguez@uam.es
}

\begin{abstract}
Resumen
La nueva regulación del procedimiento administrativo sancionador se califica por el preámbulo (V) de la Ley 18/2009, de 23 de noviembre, de reforma de la Ley de tráfico y seguridad vial, como eje central de la reforma legislativa. Entre las novedades más relevantes de esta regulación se cuenta la introducción de un procedimiento sancionador abreviado que, en realidad, más que un iter procedimental de trámites simplificados, es sólo una expeditiva forma de poner fin a un procedimiento. El presente artículo trata de ensayar una propuesta de explicación de la institución a través de la idea de ponderación de principios constitucionales realizada por el legislador. Esa construcción conduce, como consecuencia, a sostener la tesis denominada como "recurribilidad limitada" de la sanción pagada voluntariamente en cuantía reducida. Finalmente, analiza cuestiones diversas sobre el régimen jurídico-administrativo de esta institución y el de las exigencias, en relación con ella, de la prohibición constitucional del bis in idem.
\end{abstract}

Palabras clave

\section{The voluntary payment of the fines in limited quantity: legality, efficiency, juridical safety and judicial effective guardianship}

\begin{abstract}
The new regulation of the administrative sanctioning procedure is qualified by the preamble ( $V$ ) of the Law $18 / 2009$, dated November 23, of reform of the Law of traffic and road safety, as focal point of the legislative reform. Between the most relevant innovations of this regulation tells itself the introduction of a sanctioning brief procedure that, actually, more than a procedural "iter" than simplified steps, it is only an expeditious way of putting end to a procedure. The present article tries to test an offer of explanation of the institution across the idea of weighting of constitutional beginning realized by the legislator. This construction drives, as consequence, to support the thesis named like "limited resorted" of the sanction paid voluntarily in limited quantity. Finally, it analyzes diverse questions on the juridical administrative regime of this institution and that of the requirements, in relation with it, of the constitutional prohibition of the bis in idem.
\end{abstract}

Key Words

Administrative procedure, Administration sanctioning, Traffic, Road safety, Spain. 


\section{INTRODUCCIÓN: LA TERMINACIÓN DEL NUEVO “PROCEDIMIENTO SANCIONADOR ABREVIADO" Y LA EXTINCIÓN DE LA RESPONSABILIDAD DEL IMPUTADO POR EL PAGO VOLUNTARIO DE LA MULTA EN CUANTÍA REDUCIDA}

La nueva regulación del procedimiento administrativo sancionador se califica por el preámbulo (V) de la Ley 18/2009, de 23 de noviembre, de reforma de la Ley de tráfico y seguridad vial, como "eje central de la reforma" legislativa. Entre las novedades más relevantes de esta regulación se cuenta la introducción de un "procedimiento sancionador abreviado" que, en realidad, más que un iter procedimental de trámites simplificados, es sólo una expeditiva forma de poner fin a un procedimiento. Si, notificada la denuncia, se paga voluntariamente, en el acto o en el plazo de 15 días naturales, el 50 por 100 de la multa vinculada a la infracción que se imputa, la ley establece que se termine automáticamente el procedimiento (nuevos arts. 79.1 y 80 LTSV).

Esta forma de terminar el procedimiento tiene como efectos, en el plano procedimental, que la Administración tiene prohibido en el futuro tramitar cualquier otro expediente dirigido a exigir responsabilidad sancionadora del sujeto que ha pagado por los mismos hechos; y, en el plano sustantivo, que se extingue la responsabilidad (la administrativa; más abajo se tratará de la eventual responsabilidad penal) sancionadora del que ha pagado voluntariamente, sin que -en muchos casos- la sanción compute como antecedente en el Registro de Conductores e Infractores [art. $80 \mathrm{~g}$ ) LTSV].

Se vale la Ley, pues, de la institución -ya conocida desde hace décadas en nuestra legislación sobre tráfico- del pago voluntario de la sanción en cuantía reducida como forma de terminación del procedimiento administrativo y de extinción

1 Los citados arts. 79.1 y 80 LTSV prevén un plazo de 15 días naturales para realizar el pago. Sin duda, se trata de un error el plazo de 20 días naturales al que se refiere el art. 74.3 d) LTSV: en la denuncia deberá indicarse que el imputado "dispone de un plazo de veinte días naturales (¿?) para efectuar el pago, con la reducción y las consecuencias establecidas en el art. 80". Destaca la contradicción Tomás Cano Campos, "Ordenación del tráfico de vehículos y personas”, Anuario de Derecho Municipal, núm. 3 (2010), p. 392. El texto de la Ley 18/2009, de 23 de noviembre, no es -a mi juicio- un buen ejemplo de rigor en la técnica legislativa, ni en la mínima distinción en el lenguaje que puede exigirse a la redacción de una ley. Después se hará un comentario a la confusión que supone establecer una analogía entre el pago voluntario de la multa y los denominados “juicios rápidos” (preámbulo, V). Un tono -en mi opinión- excesivamente coloquial se detecta, además, en otros pasajes del preámbulo. En su mismo comienzo se refiere, por ejemplo, a la "nueva arquitectura jurídica de la autorización para conducir". A mi juicio, podría discutirse sobre la conveniencia de utilizar la metáfora de la "arquitectura" para referirse, por ejemplo, a las instituciones de la Unión Europea o del Estado. Pero hablar de una arquitectura jurídica de un acto administrativo parece, al menos, desmesurado. Se ha colado, también en el preámbulo, la fórmula que Fernando Lázaro Carreter, El dardo en la palabra, Barcelona, 1997, pp. 355 y ss. (“señalar por último que...") calificó como "chino de chiste" (p. 358): "En este sentido, destacar la nueva..." (preámbulo, II). El descuido pasa también al articulado. Establece el nuevo art. 9.2 LTSV que "los conductores deben utilizar el vehículo con 154 la diligencia, precaución y no distracción (¡!) necesarias para evitar todo daño (... )”. No es necesario insistir 
de la responsabilidad del infractor². Lo que más llama la atención de su regulación, sin embargo, es que esa forma de extinción de la responsabilidad sancionadora siempre había estado asociada a una prohibición (articulada -como se verá- a través de técnicas diversas) de que el sancionado, después de haber pagado voluntariamente, recurriera contra la sanción impuesta. La nueva Ley establece, en efecto, que la sanción aceptada y pagada en la mitad de su cuantía no puede ser objeto de recurso administrativo ninguno, ni de alzada, ni de reposición [art. 80 d) y f) LTSV]. Pero, a continuación, parece que se concede una acción plena para impugnar la sanción aceptada a través del recurso contencioso administrativo [art. 80 d) y e) LTSV].

En el presente trabajo, en primer lugar, trataré de ensayar una propuesta de explicación de la institución a través de la idea de la ponderación de principios constitucionales (legalidad, eficacia y seguridad jurídica) realizada por el legislador al regularla (abajo, II). Esa construcción conduce, como consecuencia, a sostener la tesis denominada más abajo como de la "recurribilidad limitada" (III). Quedarán para el final el análisis de cuestiones diversas sobre el régimen jurídico-administrativo de esta institución (IV) y el de las exigencias, en relación con ella, de la prohibición constitucional del bis in idem (V).

\section{UNA EXPLICACIÓN CONSTITUCIONAL DE LA SOLUCIÓN LEGISLATIVA: LA PONDERACIÓN ENTRE LOS PRINCIPIOS DE LEGALIDAD Y DE EFICACIA Y SEGURIDAD JURÍDICA}

\section{Argumentación constitucional y argumentos de política legislativa}

Es evidente que sobre una misma regulación legal puede argumentarse en un debate público desde perspectivas distintas. Con la alusión que se hace aquí a los argumentos de política legislativa quiere hacerse referencia a aquellas formas de intervenir en ese debate que ponen el acento en los efectos prácticos que la vigencia de la norma aprobada tendrá sobre la realidad social empírica que pretende regular y dirigir. La argumentación constitucional, por su parte, fija su atención sobre otros aspectos: primero, sobre la conformidad de las normas aprobadas con las reglas constitucionales de organización y procedimiento, y con los preceptos de contenido material de la Constitución (perspectiva que podría denominarse de los límites externos); y, segundo, en un plano algo más de fondo, sobre la integración sistemática de la regulación de que se trata con el orden constitucional de principios y valores que las re-

2 Utilizo la expresión, tomada del italiano (pago in misura ridotta), que introdujo entre nosotros, en el que fue -salvo error por mi parte- el primer estudio sistemático general de esta institución, Blanca Lozano, La extinción de las sanciones administrativas y tributarias, Madrid, 1990, en especial, pp. 91 y ss.; y, de la misma autora, "Procedimientos abreviados para la represión de las infracciones administrativas: el pago voluntario en cuantía reducida”, REDA, núm. 66 (1990), pp. 221 y ss. 
glas legales deben contribuir a realizar y de las que son concreción (punto de vista del sistema constitucional “interno") 3 .

No hace falta destacar que ambos modelos argumentativos no pueden estar por completo separados y que existen ámbitos de intersección de las ideas que pueden aportarse a los dos tipos de debate. Porque ni los principios y valores constitucionales se encuentran tanto (y sólo) "en el cielo de los conceptos jurídicos" como para que no puedan resultar rozados por argumentos que se extraen de la realidad social empírica; ni los valores con los que se enjuician los efectos de una norma legal en la realidad social empírica son en todo caso distintos a los que se encuentran en la norma constitucional. Mala cosa sería esto último.

En un debate de política legislativa (sancionadora, en concreto), por ejemplo, sobre el precepto legal que tipifica como infracción conducir un coche sin llevar puesto el cinturón de seguridad o una moto sin el casco [nuevo Anexo II ("infracciones que Ilevan aparejada la pérdida de puntos") de la Ley de tráfico, 18] tiene muchas posibilidades de ganar adeptos para su opinión quien demuestre con estadísticas (no debe de ser difícil) que conducir sin cinturón de seguridad o sin casco multiplica el riesgo de muerte en caso de accidente; y que prever legalmente la pérdida de puntos para quien cometa esa infracción consigue dirigir eficazmente el comportamiento de los conductores.

Sobre esta concreta cuestión el debate con argumentos jurídico-constitucionales, sin embargo, no parece ser tan sencillo. Podría argumentarse que conducir sin cinturón o sin casco no aumenta el riesgo de daños a terceros en caso de accidente, sino sólo para el propio conductor autor de la conducta. Podría llevarse al debate, también, el (frío, casi inhumano) dato de que a la sanidad y al gasto público le sale más barata la muerte (derivada de conducir sin casco) que una enfermedad prolongada (eventualmente derivada de conducir con casco), dato, por cierto, suficientemente conocido en el ámbito de la responsabilidad patrimonial de la Administración.

Y sobre esta base será necesario comenzar un matizado discurso -en el que es muy difícil que las opiniones personales prejurídicas no encuentren buenos apoyos en preceptos constitucionales- sobre si el derecho al libre desarrollo de la personalidad (art. 10.1 CE) impone, por principio, un respeto a las opciones autorreferentes del sujeto (aquéllas sin daño para terceros) ${ }^{4}$; o si el Estado, tras una

3 Se utiliza el concepto de "sistema interno" en su sentido metodológico clásico. Vid., por ejemplo, Karl Larenz, Metodología de la Ciencia del Derecho, trad. esp. de la $4^{\text {a }}$ ed. alemana, Barcelona, 1994, pp. 374-375; Claus-Wilhelm Canaris, El sistema en la Jurisprudencia, trad. esp. de la $2^{\mathrm{a}}$ ed. alemana (Systemdenken und Systembegriff in der Jurisprudenz) de 1983, Madrid, 1998, pp. 59-61; K. F. Röhl, Allgemeine Rechtslehre, Colonia-Berlín-Bonn-Múnich, 1995, p. 441-443; K. Tipke, Die Steuerrechtsordnung, tomo I, Colonia, 1993, pp. 111-112.

1564 Javier Jiménez Campo, “Comentario al art. 10.1”, en María Emilia Casas Baamonde y Miguel Rodríguez-Piñero y Bravo-Ferrer (dir.), Comentarios a la Constitución Española. XXX Aniversario, Madrid, 
adecuada ponderación entre bienes y derechos constitucionales, en concreto, tras la ponderación de ese derecho del art. 10.1 CE con la vertiente objetiva del derecho a la vida (art. 15 CE) -que impone al Estado obligaciones de protección de ese bien jurídico distintas y adicionales a las que se derivarían de la mera pretensión subjetiva de su titular-, puede adoptar la decisión normativa, calificada por algunos como de "paternalista", de proteger a las personas, incluso, "contra ellas mismas"'.

En un ámbito de cuestiones del Derecho de las infracciones y sanciones de tráfico mucho menos graves que ésta se sitúa la de la regulación del pago voluntario de la multa en cuantía reducida. El debate sobre ella se ha situado mayoritariamente -según creo- en el plano de su oportunidad y eficacia desde la perspectiva de la política legislativa.

Ahí la coloca, por lo pronto, la exposición de motivos de la Ley 18/2009, de 23 de noviembre, de reforma de la Ley de tráfico. En general -se dice- el objetivo de la reforma del régimen sancionador pretende "profundizar en la idea de la sanción de tráfico como un elemento de seguridad preventiva en la conducción: se trata de evitar la producción de los accidentes ocasionados por un comportamiento infractor. Diferentes experiencias adoptadas en países de nuestro entorno dejan claro que una adecuada gestión del procedimiento sancionador influye de modo directo en la reducción de la siniestralidad" (Preámbulo, I). En concreto, a las "ventajas evidentes" que para Administración e infractor se derivan del pago voluntario de la sanción en cuantía reducida "hay que añadir el refuerzo del principio antes apuntado de la sanción como elemento de seguridad activa, toda vez que se afianza en los conductores la configuración de una justicia administrativa vial que actúa con inmediatez y se aleja de sensaciones de impunidad" (Preámbulo, V).

Pero también este tipo de explicaciones han sido frecuentes por parte de quienes se mueven con soltura en el ámbito de la doctrina del Derecho público, constitucional y administrativo. Blanca Lozano utiliza el criterio de la eficiencia, implícita en la economía procesal, como "justificación extrajurídica” que llevará a "aceptar o rechazar" esta institución ${ }^{6}$. Alejandro Huergo sostiene que la Administración care-

2009, pp. 188-189, que deja la cuestión abierta y cita la jurisprudencia constitucional que la ha tratado más directamente.

5 Se refieren expresamente a los casos del cinturón de seguridad y del casco, en este contexto, Tomás Prieto Álvarez, La dignidad de la persona, Madrid, 2005, pp.208-209; Fernando Rey Martínez, Eutanasia y derechos fundamentales, Madrid, 2008, p. 168; Carmen Tomás-Valiente Lanuza, La disponibilidad de la propia vida en el Derecho penal, Madrid, 1999, pp. 68-70.

6 Blanca Lozano, La extinción..., pp. 125-126. La idea se expresa en los siguientes términos: “para aceptar o rechazar esta institución, se deberá valorar, por tanto, si la obtención de una mayor economía procesal en aras del principio de eficiencia del ordenamiento sancionador administrativo es una razón suficiente para justificar la existencia de una medida que fomenta una relativa desigualdad de los interesados ante el derecho a la defensa, valoración en la que incidirán numerosos factores de índole no estrictamente jurídica: sobrecarga de trabajo de las instancias administrativas y jurisdiccionales, efectividad práctica y aceptación popular de la institución, etc." 
ce de la suficiente "capacidad efectiva de gestión" como para tramitar los expedientes sancionadores que le obligarían a incoar las normas administrativas con la diligencia necesaria para que puedan resistir decorosamente un proceso de revisión judicial, por lo que la conformidad se presenta como "una salida fácil a este problema: se perdona fácilmente la sanción a cambio de una renuncia parcial a los derechos de defensa"7. Alejandro Nieto, por último, que no se refiere, en concreto, a la regulación del pago voluntario en cuantía reducida, pero sí al ámbito de las sanciones de tráfico, se vale de argumentos que podrían haber servido de modelo para la redacción de los párrafos transcritos de la exposición de motivos de la Ley 18/2009, de 23 de noviembre: "A la Administración -como a la sociedad en generalno le preocupa que un infractor quede impune (no sea retribuido) sino que con la sanción -e incluso con la amenaza de ella- procure no infringir y que, en definitiva, el tráfico sea más seguro y más fluido. Pues bien, probado está que en ocasiones es más eficaz a estos efectos la benevolencia que el rigor y tal es la política que se sigue actualmente en casi todas las Administraciones, al menos para las infracciones de masas" 8 .

Que lo que realmente se encuentra detrás de la regulación del pago voluntario en cuantía reducida es algo de todo esto me parece indudable. Pero, cuando una regulación legislativa en una materia de relevancia constitucional -la tiene en nuestro Derecho la materia administrativa sancionadora, por su conexión con la penal, quizás más de la que sería obligada9 - deja de debatirse en el Parlamento y se publica en el Boletín Oficial del Estado, esa regulación se separa en parte de las motivaciones políticas que dieron lugar a ella y ofrece también otra posible cara de análisis y explicación, que es la que se intenta a continuación.

\section{La ponderación de principios constitucionales que está detrás de la solución legislativa}

En nuestro sistema constitucional de división de poderes parece claro que el primer llamado a ponderar entre principios en situación de tensión recíproca (en especial, los de rango constitucional, pero no sólo ellos), mediante el establecimiento de reglas que los concreten y den prevalencia a unos sobre otros en función de las circunstancias que deban considerarse determinantes para ello, es el legislador ${ }^{10}$. Por otra parte, donde existieran diversas posibilidades teóricas de dar

7 Alejandro Huergo Lora, Los contratos sobre los actos y las potestades administrativas, Madrid, 1998, p. 428.

8 Alejandro Nieto, Derecho administrativo sancionador, $4^{\text {a }}$ ed., Madrid, 2005, p. 134.

9 Ya ha empezado a ser habitual la crítica a la corriente que, con entusiasmo, siguió a la aprobación de la Constitución española de 1978 de equiparar sanciones administrativas y penales. Entre las últimas revisiones críticas está la de Alejandro Huergo Lora, Las sanciones administrativas, Madrid, $2007, \mathrm{pp}$. 15-16, passim.

10 José María Rodríguez de Santiago, La ponderación de bienes e intereses en el Derecho administra-

158 tivo, Madrid - Barcelona, 2000, p. 59. 
prevalencia a un principio o a otro, una vez que el legislador se ha decidido a favor de una de ellas, a la misma quedan vinculados los órganos judiciales y los del poder ejecutivo ${ }^{11}$.

El principio de legalidad (art. 9.3 CE) en el ejercicio del ius puniendi estatal (opuesto, en el contexto que aquí interesa, al principio de oportunidad y al principio dispositivo) exigiría que, una vez iniciado un procedimiento sancionador, el Estado lo tramitara íntegramente con el objeto de averiguar la verdad material y vinculara a los hechos probados, como consecuencia jurídica, la sanción prevista con carácter general en la ley para la infracción de que se trate ${ }^{12}$. La regulación del pago voluntario de la multa en cuantía reducida supone una excepción evidente a este principio. La Administración renuncia a investigar la verdad material de los hechos y acepta la verdad formal derivada de que sobre la imputación provisional de responsabilidad que supone la denuncia haya recaído el consentimiento del denunciado. Y se renuncia también a la mitad de la extensión a la que la Administración podría llevar la pretensión sancionadora pecuniaria.

Pero el legislador considera justificado el perjuicio que se causa al principio de legalidad por las ventajas que el pago voluntario en cuantía reducida trae consigo desde la perspectiva de los principios de eficacia administrativa (art. 103.1 CE) y de seguridad jurídica (art. 9.3 CE). El "borrón y cuenta nueva” que la ley vincula al pago voluntario de la multa en cuantía reducida permite a la Administración sancionadora descargarse del trabajo derivado de la tramitación masiva de muchos "asuntos bagatela" y concentrar sus energías en los casos legalmente más relevantes o de difícil tramitación. La terminación automática del procedimiento administrativo y la garantía de que no se replanteará cuestión alguna en vía administrativa derivada de esos hechos ya sancionados favorecen directamente la adquisición inmediata de certeza sobre las situaciones jurídicas.

En este conjunto de ideas ha situado, por ejemplo, el Tribunal Constitucional el sentido de alguna institución en parte análoga a la que nos interesa, como es la conformidad a las actas de inspección en el ámbito del Derecho tributario, cuyos efectos tienen la finalidad de "agilizar y flexibilizar el cobro de las deudas" [STC 76/1990, de 26 de abril, FJ 7 B)] y servir a la "simplificación y celeridad en los procedimientos" [STC 76/1990, FJ 7 A)].

Que la ley ofrezca al denunciado la posible solución de pagar voluntariamente la mitad de la multa a cambio de que el asunto quede en vía administrativa cerrado para

11 Larenz, Metodología..., p. 339, al referirse al primado de “concretización” de los principios por el legislador.

12 Vid., por ejemplo, para el ámbito del Derecho y del proceso penal, Silvia Barona Vilar, La conformidad en el proceso penal, Valencia, 1994, pp. 217, 222-223, passim.; Pedro M. Butrón Baliña, La conformidad del acusado en el proceso penal, Madrid, 1997, pp. 44 y ss., bajo el epígrafe "el principio de legalidad en el proceso penal". 
siempre y los hechos "borrados del mapa" ${ }^{13}$ supone, pues, una regulación a través de la cual el legislador ha encontrado un punto de equilibrio adecuado entre principios constitucionales abstractamente enfrentados: menos principio de legalidad a cambio de más eficacia, economía procesal y seguridad jurídica.

A mi juicio, la identificación de los principios que el legislador ha ponderado en la regulación del pago voluntario de la multa en cuantía reducida y, en concreto, la simple afirmación de que esa regulación responde a un juicio ponderativo llevado a cabo por el legislador son de utilidad en la tarea de interpretar correctamente el sentido y el alcance de las reglas que disciplinan la terminación del procedimiento sancionador abreviado. Porque decir que detrás de esa solución legislativa existe una decisión adoptada por ponderación entre principios contrapuestos implica ofrecer al intérprete un criterio metodológico útil para su tarea, como es el de las exigencias de la llamada "ley de la ponderación" que ha de cumplirse siempre que una decisión se adopte a través de esa forma de solucionar conflictos entre principios: "cuanto mayor sea el grado de perjuicio a uno de los principios en colisión mayor ha de ser la importancia del cumplimiento de su contrario""14.

Algunas cuestiones problemáticas que suscita la regulación de la institución [especialmente, aunque no sólo, el alcance de la recurribilidad en vía contencioso administrativa a la que hace referencia expresa el art. 80 d) y e) LTSV] encuentran solución adecuada a través de esta interpretación que tiene en cuenta que detrás del pago voluntario hay principios con exigencias que deben compensarse; y, en general, el conjunto de la regulación se deja integrar de esta manera en una explicación armónica y coherente en torno a los principios entre los que el legislador ha buscado un punto de equilibrio.

\section{Primera consecuencia jurídica de este modelo explicativo: el equilibrio entre los principios ponderados exige limitar la recurribilidad en vía contencioso administrativa de la sanción pagada voluntariamente en cuantía reducida}

En todos los modelos comparados de regulación de instituciones análogas a la del pago voluntario de la multa en cuantía reducida la renuncia parcial del Estado a su pretensión punitiva va acompañada de la renuncia del ciudadano a su derecho a recurrir" $^{15}$. Sin embargo, a pesar de que "en todos los supuestos de pago en cuantía reducida que reconoce nuestro ordenamiento es una constante (...) la no admisión de la

13 En la doctrina alemana sobre la institución análoga al pago voluntario en cuantía reducida, el Verwarnungsgeld, regulado en el $\S 56$ de la Gesetz über Ordnungswidrigkeiten, se utiliza una expresión semejante: aus der Welt schaffen.

14 La cita ya es suficientemente conocida también en nuestro Derecho: Robert Alexy, Theorie der Grundrechte, $3^{\text {a }}$ ed., Frankfurt a. M., 1996, p. 146, passim.

15 Así, Lozano, La extinción..., p. 119, en el contexto del análisis comparado del alcance de la prohibición de recurrir el pago voluntario en cuantía reducida. 
posibilidad de recurrir del infractor que se acoge a esta institución"16; y a pesar de que -como acaba de decirse- también en el Derecho comparado es unánime -porque pertenece a la naturaleza de esta forma de extinción de las infracciones administrativas y de terminación del procedimiento administrativo sancionador- la negación del acceso al recurso administrativo o judicial frente a aquello que se ha aceptado, la reciente reforma de la regulación del pago voluntario en cuantía reducida de las multas de tráfico, de forma tan generosa como sorprendente, ha previsto que éstas son recurribles ante el orden jurisdiccional contencioso administrativo [art. 80 c) LTSV]; y que el plazo para interponer ese recurso se iniciará el día siguiente a aquél en que tenga lugar el pago [art. 80 e) LTSV].

La nueva regulación prevé que con el pago voluntario concluya automáticamente el procedimiento sancionador abreviado (art. 80 LTSV), que si se formularan alegaciones, éstas se tengan por no presentadas [art. 80 a) LTSV] y que no cabe recurso administrativo ni de alzada, ni de reposición [art. 80 d) y f) LTSV]. Pero parece que se concede una acción plena para impugnar la sanción aceptada a través del recurso contencioso administrativo.

La perplejidad es la única reacción posible al caer en la cuenta de esta sorprendente generosidad que, de hecho, quiebra el equilibrio entre principios que -según se ha expuesto- está detrás de la institución.

En la regulación del régimen sancionador en materia de tráfico derogada por la reforma llevada a cabo por la Ley 18/2009, de 23 de noviembre, se establecía que el abono del importe (íntegro) de la multa antes de que hubiera terminado el procedimiento (esto es, un "pago voluntario") podía dar lugar, en algunos casos, a la finalización del expediente "sin perjuicio de la posibilidad de interponer el recurso correspondiente" (art. 77.2 LTSV, en su anterior redacción). Una regla parecida establece, con aplicación general a cualquier procedimiento sancionador -no sólo en materia de tráfico-, el art. 8.2 RPPS (párrafo primero): "cuando la sanción tenga carácter pecuniario, el pago voluntario por el imputado, en cualquier momento anterior a la resolución, podrá implicar igualmente la terminación del procedimiento sin perjuicio de la posibilidad de interponer los recursos procedentes". Aquí no hay renuncia alguna a la pretensión sancionadora estatal, no hay perjuicio alguno al principio de legalidad desde la perspectiva que ahora nos interesa, por lo que no estaría justificado que la voluntariedad en el pago se entendiera como una renuncia a la facultad de recurrir contra la resolución sancionadora.

Pero el perjuicio al principio de legalidad en la imposición de la pretensión sancionadora estatal que supone la institución del pago voluntario en cuantía reducida sólo está justificado -conforme a la "ley de la ponderación" a la que se ha hecho referenciasi realmente se gana algo sustancial desde la perspectiva de los principios de eficacia, de

16 Lozano, "Procedimientos...", p. 243. 
economía procesal y de seguridad jurídica. Y si se establece que no cabe el recurso administrativo, pero sí el jurisdiccional, nada se ha ganado desde esta triple perspectiva.

Ninguna ventaja se obtendría desde el punto de vista de la seguridad jurídica, porque todo lo resuelto a través del consentimiento del imputado en el procedimiento administrativo abreviado (la realidad de los hechos, su calificación jurídica, eventuales defectos formales, etc.) podría volver a plantearse para su resolución por el órgano judicial que conozca del recurso contencioso administrativo. Carece, además, de toda justificación que la ley descargue a la Administración que tramita estos procedimientos prohibiendo el recurso administrativo, pero a costa de concentrar la carga de las impugnaciones que se ofrecen magnánimamente al sancionado en el orden jurisdiccional contencioso administrativo. ¿Qué sentido tiene descargar de trabajo a la Administración, pero no a los órganos judiciales?

Además, esta regulación descarga a la Administración de la tramitación de recursos administrativos, pero no del peso de ser parte procesal en los recursos jurisdiccionales que se ponen a disposición del sancionado. ¿Qué se gana, por último, desde la perspectiva de la economía procesal, si con esta regulación se impone al órgano judicial la exigencia de "reconstruir" los expedientes administrativos sancionadores, pues los que le remita la Administración constarán tan sólo de una denuncia y de un documento acreditativo del pago de la mitad de la multa? El expediente carecerá de contenido precisamente a causa de la conformidad del imputado que, después, pide su revisión jurisdiccional' ${ }^{17}$.

Para restablecer el equilibrio entre los principios que están detrás de la regulación legal del pago voluntario de la multa en cuantía reducida es necesario conseguir que la excepción al principio de legalidad implícita en la institución esté efectivamente justificada por las ventajas que deben derivarse de ella para los principios de eficacia, economía procesal y seguridad jurídica. $Y$, para ello, debe interpretarse que la expresa referencia legal al recurso contencioso administrativo alude a una vía jurisdiccional de impugnación por motivos tasados. Esta tesis de la recurribilidad limitada será desarrollada más adelante.

\section{Segunda consecuencia jurídica: explicación de la prohibición de desproporción entre la sanción prevista con carácter general para la infracción y la sanción que se impone si media el consentimiento}

Desde que se dictó la STEDH de 27 de febrero de 1980, caso Deweer ${ }^{18}$, constituye cuestión de obligado tratamiento en esta materia -en los análisis de las instituciones

17 Huergo, Los contratos..., p. 425.

18 Sobre esta sentencia vid. Luis Ortega Álvarez, "La coacción institucional para desistir del acceso al juez", RAP, núms. 100-102 (1983), pp. 1437 y ss.; Lozano, La extinción..., pp. 128-130; Huergo, Los contratos..., pp. 431-432. 
del Derecho procesal penal y administrativo sancionador que dan acogida a la idea de la renuncia del Estado a parte de su pretensión punitiva a cambio de la renuncia al derecho a recurrir- la de la prohibición de desproporción entre la sanción prevista con carácter general para la infracción que se imputa y la que se impone si el imputado consiente y acepta no recurrir. En el caso del Sr. Deweer, el Derecho belga le situó ante la alternativa de pagar 10.000 francos belgas (y no recurrir) o atenerse a las consecuencias derivadas de la terminación normal del procedimiento $y$, sobre todo, aceptar que cautelarmente se le cerrara el establecimiento comercial del que era titular. El TEDH estimó que la desproporción entre los dos términos de la alternativa determinó una coacción que vulneró el derecho a un juicio justo del art. 6.1 del Convenio Europeo de Derechos Humanos.

Esta prohibición de desproporción también puede explicarse con ayuda de la idea de que el pago voluntario en cuantía reducida es una solución que el legislador adopta en un juicio de ponderación entre principios contrapuestos, en el que debe cumplirse con la "ley de la ponderación" de que un perjuicio grave en un principio puede estar justificada por una ventaja notable que se obtenga para otro principio contrapuesto; pero un perjuicio grave en uno de los términos de la ponderación no se compensa con un leve beneficio para el otro.

Una rebaja en la sanción que no exceda del grado estrictamente necesario para que el ciudadano esté interesado en zanjar la situación voluntariamente aceptándola ${ }^{19}$ puede estar justificada por el beneficio que se obtiene desde la perspectiva de la eficacia, la economía procesal y la seguridad jurídica. Pero difícilmente puede argumentarse que moderadas ventajas para la eficacia y la seguridad jurídica sirvan para justificar una desviación desmesurada en el tipo o en el grado de la sanción que puede imponerse si el imputado se pliega a la imputación de responsabilidad sancionadora por parte del Estado. Una alteración de grado en uno de los platos de la balanza no puede compensarse por una modificación cualitativa en el otro. La rebaja de la sanción ha de moverse, pues, en la franja que resulta, por una parte, de la línea de lo que puede hacer su aceptación interesante para el imputado y, por otra, de la línea que marca dónde empieza la desproporción.

Así puede explicarse que no sea admisible la solución que diera a elegir entre pagar voluntariamente 3 o exponerse a tener que pagar $100^{20}$. A mi juicio, el problema

19 Una rebaja irrelevante en la sanción, evidentemente, no interesará al ciudadano imputado lo suficiente como para aceptar los perjuicios derivados del consentimiento. Destaca Huergo, Los contratos..., p. 427, que "la razón por la que se reduce la cuantía de la sanción en caso de conformidad no es la menor gravedad de la infracción, sino el intento de neutralizar el ejercicio por el particular de sus derechos de defensa".

20 El ejemplo lo pone Huergo, Los contratos..., p. 430 (en nota núm. 69), que lo refiere a las multas en materia de regulación del aparcamiento (ORA): "si el ciudadano paga, en un breve plazo a contar desde la emisión de la denuncia, una pequeña cantidad, el procedimiento sancionador no llega a iniciarse. La relación entre ambas cantidades es absolutamente desproporcionada (las cantidades pueden ser unas 300 pesetas en el caso de la anulación de la denuncia, frente a las 10.000 de la sanción)". 
no es tanto de derechos fundamentales -esto es, subjetivo- como de desequilibrio objetivo en la regulación. Si no es desproporcionada la sanción de pagar 100 vinculada al tipo de infracción que se imputa, se entiende mal que, desde el punto de vista de los derechos fundamentales, de los intereses subjetivos del imputado, se impida a éste liberarse de semejante sanción eventual mediante el sencillo pago de 3 . De la desproporción sale ganando el individuo ${ }^{21}$.

El verdadero problema se encuentra, en mi opinión, en el desprecio objetivo al principio de proporcionalidad en la regulación de las sanciones por parte del legislador que se manifiesta en una regulación semejante, que inevitablemente proyecta una sombra de arbitrariedad en la alternativa que ofrece la ley al imputado. Yo creo que lo que sucede es que, como en otros ámbitos situados en torno a las exigencias del art. 25.1 CE (que, al fin y al cabo, es una norma objetiva relativa al sistema de fuentes convertida en un derecho subjetivo fundamental) ${ }^{22}$, los defectos objetivos de la regulación fácilmente terminan considerándose vulneraciones de ámbitos subjetivos de libertad o autodeterminación. Que, después, la vulneración se sitúe en el ámbito -por utilizar la numeración de nuestro catálogo constitucional de derechos fundamentales- del art. 25.1 CE o del art. 24 CE (como hace el TEDH en el caso Deweer) es, en algunas ocasiones, cuestión de "arbitrio judicial"23.

Parece una adecuada solución la de fijar la cuantía de la sanción reducida a través de un porcentaje que ha de aplicarse sobre la base de la sanción prevista con carácter general para la infracción que se imputa. De esta forma queda garantizado que siempre existirá una proporción entre la sanción reducida y el reproche en términos de sanción que el legislador ha vinculado a las diversas infracciones. La reducción del 50 por 100 del importe de la sanción de multa [art. 80 a) LTSV] es una solución generosa, pero no desproporcionada. Téngase en cuenta que -como se dirá más adelante-, por ejemplo, la eventual sanción de la pérdida de puntos no es objeto de reducción.

El Código de la Circulación de 1934, desde la reforma llevada a cabo por el Decreto 3268/1968, había fijado la reducción en un 20 por 100 (art. 287), porcentaje que se respetó en la primera redacción del art. 67 de la Ley sobre tráfico, circulación de vehículos a motor y seguridad vial, de 1990. El porcentaje de reducción ya había subido al 30 por 100 en la redacción que a dicho art. 67 de la Ley de tráfico otorgó la Ley 19/2001, de 19 de diciembre.

21 Un argumento semejante utilizó el Gobierno belga en el proceso resuelto por la mencionada STEDH de 27 de febrero de 1980. A la alegación respondió el Tribunal con el conocido tópico de que "in the area of human rights he who can do more cannot necessarily do less" (Deweer, § 53 ).

22 Así, Nieto, Derecho administrativo..., p. 220: "la legalidad es un principio normativo y, por ende, forma parte del Derecho objetivo. Pero, por otro lado y como sucede de ordinario, de ese Derecho objetivo se deriva uno de índole subjetiva, que consiste en el derecho a exigir que sea respetada la legalidad" (cursiva mía).

$164 \quad 23 \quad$ Utilizo la expresión en el sentido polémico que 
En el plano abstracto de los posibles modelos regulatorios, el de la ley española me parece mejor, por ejemplo, que el alemán del $\S 56$ de la Gesetz über Ordnungswidrigkeiten, en el que el Verwarnungsgeld se regula como una sanción autónoma, impuesta sobre la base del consentimiento del imputado en un procedimiento previo al propiamente sancionador, cuya cuantía no guarda relación directa con la prevista para la sanción correspondiente a la infracción que se imputa ${ }^{24}$. No obstante, la exigencia de proporcionalidad en este sistema queda, con carácter general, satisfecha, si se tiene en cuenta que la cuantía del Verwarnungsgeld (entre 5 y $35 €$ ) ha de ponerse en relación con el requisito legal de que éste se permite únicamente en el caso de infracciones leves (geringfügig).

\section{LA RECURRIBILIDAD LIMITADA DE LA SANCIÓN REDUCIDA VOLUNTARIAMENTE PAGADA}

\section{Dos técnicas posibles para garantizar que el perjuicio a la pretensión sancionadora del Estado se vea compensado por el beneficio a la eficacia administrativa, la economía procesal y la seguridad jurídica}

Se ha dicho más arriba que para mantener el equilibrio entre los principios que están detrás de la regulación legal del pago voluntario de la multa en cuantía reducida es necesario asegurar que la excepción al principio de legalidad implícita en la institución esté efectivamente justificada por las ventajas que deben derivarse de ella para los principios de eficacia, economía procesal y seguridad jurídica; y que, para ello, debe interpretarse que la expresa referencia legal al recurso contencioso administrativo [art. 80 c) y e) LTSV] alude a una posible recurribilidad limitada de la sanción pagada voluntariamente en cuantía reducida.

En instituciones análogas a la del pago voluntario en cuantía reducida, nuestro Derecho público ha conocido dos técnicas para garantizar el mantenimiento de ese equilibrio entre los principios en situación de tensión o, lo que en este contexto es lo mismo, que no se vea perjudicada la pretensión sancionadora del Estado sin que, al mismo tiempo, salga ganando la eficacia administrativa, la economía procesal y la seguridad jurídica. La primera es la de someter la eficacia del beneficio para el imputado vinculado a la terminación del procedimiento por aceptación (y, en su caso, también, pago) a la condición resolutoria de que no se recurra la resolución sancionadora. La ley no prohíbe recurrir, pero si posteriormente se recurre, el beneficio se pierde. La segunda es, lisa y llanamente, declarar indamisible el recurso interpuesto contra aquella parte del contenido decisorio de la resolución que ha sido aceptada por su destinatario. Analicemos la cuestión con algo más de detenimiento.

24 Vid., por ejemplo, Rebmann, en Kurt Rebmann, Werner Roth y Siegfried Hermann, Gesetz über Ordnungswidrigkeiten. Kommentar, tomo 1, Stuttgart - Berlin - Köln - Mainz, 1983, comentario previo al § 56, marginal 1; Erich Göhler, Gesetz über Ordnungswidrigkeiten, Múnich, 1995, pp. 401-402 (que parece, no obstante, discutir la naturaleza sancionadora del Verwarnungsgeld); Volkhard Wache, en Karlheinz Boujong (coord.), Karlsruher Kommnentar zum Gesetz über Ordnungswidrigkeiten, Múnich, 1989, pp. 650-651. 
Para la conformidad a las actas de la inspección de los tributos ${ }^{25}$ el Derecho positivo se ha servido, durante un tiempo, de la primera técnica. La conformidad a dichas actas es, en lo que ahora nos interesa, una institución análoga a la que estamos analizando. Las diferencias existentes entre los elementos que definen ambas regulaciones ${ }^{26}$ no afectan a lo que va a decirse. El art. 21.2 del Reglamento sancionador tributario (aprobado por Real Decreto 1930/1998, de 11 de septiembre, vigente hasta octubre de 2004) disponía que, cuando el sujeto infractor manifestara su conformidad con la propuesta de regularización de su situación tributaria, la cuantía de la sanción pecuniaria se reduciría en un 30 por 100; pero "la posterior interposición de cualquier recurso o reclamación contra el acto administrativo que contenga la regularización (...) determinará la exigencia del importe de la reducción practicada (...)”.

Ya antes de que entrara en vigor esta regulación reglamentaria de la conformidad a las actas de inspección de los tributos, el Tribunal Constitucional había tenido la oportunidad de pronunciarse sobre la constitucionalidad de algunos de los efectos previstos para la conformidad en la Ley 10/1985, de 26 de abril, de modificación parcial de la Ley General Tributaria. La redacción que dicha Ley otorgó al art. 82 h) LGT dispuso que la conformidad del sujeto pasivo se tuviera en cuenta como criterio para graduar las sanciones tributarias. La ley no prohibía expresamente que, después de haber prestado la conformidad, el obligado tributario impugnara la sanción.

La situación era, pues, la de que "la Ley no obliga al contribuyente a prestar su conformidad, ni impide tampoco que, una vez prestada ésta, se puedan ejercitar las acciones de impugnación". Lo más destacable de lo que nos interesa es que es la propia sentencia la que, a renglón seguido, declara que es "lógico", sin embargo, "aunque la Ley no lo diga, que si se impugna la liquidación y la correspondiente multa, en cuya determinación se ha tenido en cuenta por la Administración la conformidad a la propuesta de liquidación de la deuda tributaria, deje entonces de operar ese criterio y su efecto de disminución de la cuantía. Mantener la conformidad es, pues, una facultad -no una obligación, ni siquiera un deber- para conservar el beneficio de su consideración como un elemento más en la graduación in medius de la cuantía de la sanción tributaria" [STC 76/1990, de 26 de abril, FJ 7 A) ]27.

25 Sobre esto vid., entre los muchos trabajos doctrinales existentes, Juan Arrieta Martínez de Pisón, Las actas de la inspección de los tributos, Madrid, 1994, pp. 349 y ss.

26 Son analizadas por Lozano, La extinción..., pp. 110 y ss., bajo el epígrafe “desvirtuación del pago en cuantía reducida en el Derecho tributario: de la condonación automática a la conformidad del contribuyente como criterio de la graduación de la sanción".

27 La técnica de la condición resolutoria de beneficios en las sanciones también es conocida en la legislación sobre tráfico, aunque no exactamente en el ámbito del pago voluntario en cuantía reducida. La antigua redacción del art. 67.1 LTSV (tras la reforma llevada a cabo por la Ley 19/2001, de 19 de diciembre) permitía que la cuantía de la sanción pecuniaria y el período de suspensión del permiso o licencia de conducción se redujeran hasta un 30 por 100 de su totalidad y se sustituyeran, a petición del sancionado, por medidas reeducadoras (cursos de comportamiento, módulos de concienciación, etc.). Pues bien, si después se producía un incumplimiento de las medidas reeducadoras, el beneficio se perdía y surgía "la obli166 gación de pago inmediato de la parte de la multa sustituida junto a los recargos que procedan” (antiguo 
La segunda técnica de la que se sirve la legislación para garantizar el equilibrio entre el perjuicio a la pretensión sancionadora del Estado (principio de legalidad) y el beneficio a la eficacia administrativa, la economía procesal y la seguridad jurídica como se ha dicho- es, pura y simplemente, la de declarar indamisible el recurso interpuesto contra aquella parte del contenido decisorio de la resolución que ha sido aceptada por su destinatario. Nótese que no es necesario que se declare la inadmisibilidad de cualquier tipo de impugnación, sino sólo de la que se basara en motivos cuya invocación fuera contradictoria con la conformidad que se había prestado para obtener un beneficio. Que detrás de esta fórmula (aunque también detrás de la condición resolutoria referida) se encuentra el principio venire contra factum proprium non valet es una evidencia ${ }^{28}$.

También la legislación tributaria relativa a las actas de conformidad se ha servido, en ocasiones, de esta solución. El art. 61.2 del Reglamento general de la inspección de los tributos (aprobado por Real Decreto 939/1986, de 25 de abril, vigente hasta enero de 2008) establecía que "en ningún caso podrán impugnarse por el obligado tributario los hechos y los elementos determinantes de las bases tributarias respecto de los que dio su conformidad, salvo que pruebe haber incurrido en error de hecho". La interpretación -a mi juicio- más plausible de este precepto entendía que lo que no podía cuestionarse en vía de recurso eran tanto los "hechos" como las "calificaciones jurídicas"29 (el resultado de la subsunción de esos hechos bajo las normas aplicables llevada a cabo por la Administración) a las que se había prestado aceptación. Otros aspectos de la decisión administrativa y del procedimiento a través del que se había dictado sí podían impugnarse, en este caso, por ejemplo, el proceso de formación de la voluntad para otorgar el consentimiento por parte del obligado tributario. Aquí está diseñada la solución de la recurribilidad limitada.

\section{Un criterio interpretativo interno a la propia ley que apoya la solución de la recurribilidad limitada}

El nuevo art. 80 LTSV menciona expresamente la posibilidad de interponer recurso contencioso administrativo contra la sanción pagada voluntariamente en cuantía reducida, pero no limita de ninguna forma los motivos de oposición a aquélla invocables en esta vía de recurso. En esta situación sería posible argumentar que, donde la ley no limita el recurso, no es posible que éste se declare inadmisible en virtud de opiniones doctrinales más o menos convincentes. Ese argumento tiene a su favor -es

28 En la doctrina alemana sobre el Verwarnugsgeld es unánime la idea de que el motivo por el que los órganos judiciales pueden rechazar el examen de una impugnación que cuestionara los hechos y su calificación jurídica (no, sin embargo, otras impugnaciones basadas en defectos formales) es que no puede aceptarse que el sancionado incurra en contradicción con sus propios actos. Vid., por ejemplo, Rebmann, en Rebmann, Roth y Hermann, Gesetz..., comentario al § 56, marginal 28; Göhler, Gesetz..., p. 412; Wache, en Boujong (coord.), Karlsruher..., p. 660.

29 Arrieta, Las actas..., pp. 436-440. Para Huergo, Los contratos..., p. 426, la regulación de las sanciones tributarias hace claro que la renuncia a recurrir está "implícita" en la conformidad con la sanción. 
innegable- el apoyo de la fuerza que la jurisprudencia constitucional ha otorgado al derecho a la tutela judicial efectiva (art. 24.1 CE) en su vertiente de acceso a la jurisdicción -como se dirá más abajo- y el alcance en esa vertiente del principio pro actione.

Aquí pretende demostrarse, sin embargo, que la solución de la recurribilidad limitada no es sólo consecuencia de argumentaciones interpretativas externas a la ley que debe interpretarse. Es el mismo legislador que ofrece el recurso contencioso administrativo el que también ofrece un criterio interpretativo (interno, por tanto, al precepto cuyo alcance debe determinarse) que fundamenta la tesis de que en el recurso jurisdiccional no es posible cuestionar los hechos imputados al sancionado y la calificación jurídica de los mismos (la subsunción bajo un tipo de infracción y la imposición de la sanción vinculada normativamente a aquélla, de la que después deberá pagarse sólo el 50 por 100).

La exposición de motivos de la Ley 18/2009, de 23 de noviembre, de reforma de la Ley de tráfico, destaca expresamente que "el procedimiento abreviado ahora diseñado -el que termina mediante el pago voluntario de la multa en cuantía reducida-es similar a los coloquialmente conocidos en el ámbito penal como juicios rápidos" (Preámbulo, V). Ya se ha dicho que ni esa exposición de motivos, en particular, ni, en general, la propia ley se caracterizan por su elegancia en el lenguaje ni por su precisión técnica. Aquí nos encontramos con una de esas incorrecciones que, sin embargo, no impiden que se entienda lo que (con torpeza) quiere decirse. Es patente que la analogía no quiere establecerla el legislador con el "procedimiento para el enjuiciamiento rápido de determinados delitos” (título III del libro IV, arts. 795 y ss. LECrim), conocidos coloquialmente como “juicios rápidos”. Juicio rápido y conformidad son dos conjuntos que sólo tienen una intersección. $\mathrm{Ni}$, evidentemente, todos los juicios rápidos terminan por sentencia de conformidad, ni la sentencia de conformidad se dicta sólo en los juicios rápidos.

La analogía quiere establecerse, en general, con la institución de la sentencia de conformidad del art. 787 LECrim; y, en concreto, con la sentencia de conformidad dictada en el procedimiento para el enjuiciamiento rápido de determinados delitos (art. 801 LECrim), para la que la ley prevé que la pena solicitada se imponga "reducida en un tercio, aun cuando suponga la imposición de una pena inferior al límite mínimo previsto en el Código Penal" (art. 801.2 LECrim).

La analogía entre la institución procesal penal de la sentencia de conformidad y la administrativa del pago voluntario de la multa en cuantía reducida no es, por descontado, un descubrimiento reciente ${ }^{30}$. Sus elementos paralelos son patentes: el Estado renuncia a apurar las posibilidades de investigar la verdad material sobre los hechos y, en mayor o menor medida, a agotar la pretensión sancionadora que le otor-

30 Puede verse sobre esto Lozano, La extinción..., pp. 103-104, de acuerdo con la regulación de la sentencia de conformidad vigente en 1990, que ha sido modificada desde entonces en varias ocasiones. 
ga la ley con carácter general; y, en contrapartida, se acepta que el procedimiento termine y que no pueda volver a discutirse sobre la cuestión (ventaja para la economía procesal y la seguridad jurídica). Para la sentencia de conformidad el art. 787.7 LECrim dispone hoy expresamente que en un recurso interpuesto frente a ella puedan discutirse las cuestiones formales que dieron lugar a la conformidad, pero los hechos y su calificación jurídica (el fondo) ya no son discutibles: “únicamente serán recurribles las sentencias de conformidad cuando no hayan respetado los requisitos o términos de la conformidad, sin que el acusado pueda impugnar por razones de fondo su conformidad libremente prestada" ${ }^{31}$.

A mi juicio, que el propio legislador declare que el procedimiento sancionador abreviado ha sido "diseñado" de forma "similar" al juicio rápido que termina por sentencia de conformidad es argumento suficiente para entender que el recurso contencioso administrativo al que se refiere al art. 80 LTSV no es una vía procesal en la que pueda replantearse aquello que se ha aceptado, sino un proceso al que sólo pueden llevarse causas determinadas de oposición a la sanción.

\section{Lo que se puede y lo que no se puede impugnar a través del recurso contencioso administrativo}

La denuncia que da lugar a la incoación del procedimiento sancionador (art. 73.1 LTSV) o que constituye ella misma acto de iniciación de ese procedimiento (art. 73.2 LTSV) contiene, en lo esencial, una "descripción sucinta" de los hechos constatados por la Administración [art. 74.2 c) LTSV] y el resultado de un (provisional) silogismo de subsunción en virtud del cual, por una parte, se considera que ese factum realiza el tipo de una infracción y, por otra, se vincula a ésta la consecuencia jurídica prevista por la norma para el supuesto de hecho infractor: la sanción [art. 74.3 a) LTSV]. Este contenido de la denuncia constituye una imputación provisional de responsabilidad sancionadora que, por disposición legal, pasa a ser una imputación definitiva si el infractor paga voluntariamente el 50 por 100 de la multa en el plazo que se le concede (art. 80 LTSV).

Los hechos imputados y su calificación jurídica (la tipificación como infracción y la sanción a ella vinculada) constituyen el objeto de lo que voluntariamente acepta el infractor para poner fin de esa manera al procedimiento. Sobre este contenido reso-

31 Ya con anterioridad a esta clara regulación se había llegado a esa solución por vía interpretativa. Puede verse sobre esto Luis-Alfredo de Diego Díez, La conformidad del acusado, Valencia, 1997, pp. 469470: "nuestro ordenamiento procesal vigente no cuenta con un apoyo legal que expresamente impida el acceso a los recursos de las sentencias dictadas por y de conformidad con la acusación más grave. Con todo, viene entendiéndose que la conformidad supone una renuncia tácita, anticipada y condicionalrespecto del doble grado jurisdiccional" (se cita jurisprudencia de los años 80 y 90). En opinión de este autor, "es del todo asumible que si la sentencia se pronuncia ajustada enteramente a la acusación objeto de conformidad, tal resolución resulte inaccesible a un nuevo enjuiciamiento (...): falta legitimación para recurrir porque no hay gravamen o perjuicio para el recurrente". 
lutivo ya no cabe discusión por parte de quien tomó voluntariamente la decisión de aceptarlo para terminar el debate. $Y$ a ese objeto se ciñe también la prohibición a la Administración de volver, en otro procedimiento, sobre aquellos hechos y su calificación jurídica. El asunto ha quedado zanjado (al menos, para la Administración; después se hablará de la jurisdicción penal) para siempre. Que la "sanción" (no un "acto administrativo", sino exactamente la sanción) sea "firme" significa en el art. 80 f) LTSV que ni el sancionado ni la Administración pueden volver a discutir sobre los hechos y la calificación jurídica que dieron lugar a ella. Aquello por lo que no es admisible recurrir al sancionado es lo mismo que aquello por lo que tampoco la Administración puede abrir un nuevo procedimiento sancionador.

La irrecurribilidad de los hechos y su calificación jurídica -lo que, convencionalmente, puede identificarse como "el fondo"- no necesariamente lleva consigo la irrecurribilidad de otros aspectos que -también convencionalmente- pueden calificarse como "de forma" 32 . A la invocación de defectos de este tipo debería limitarse la admisibilidad de la cognición judicial en el recurso contencioso administrativo al que se refiere el art. 80 LTSV.

Por lo pronto, la sanción pagada en cuantía reducida puede recurrirse por vicios que afecten, precisamente, a la voluntariedad. El art. 80 LTSV otorga eficacia terminadora del procedimiento (y eficacia impeditiva de tramitar cualquier otro administrativo por los mismos hechos) al pago voluntario, no simplemente al pago. Podrá recurrirse, en consecuencia, si la notificación de la denuncia no contenía información [imperativa según el art. 74.3 c) LTSV] para hacerse idea cabal de las consecuencias derivadas del pago; o si el pago no se realizó voluntariamente por el imputado, sino por un tercero que no ostente la representación del sancionado. En el supuesto de pago en el acto al Agente de la autoridad que formula la denuncia (arts. 73.2, 74.3 y 80 LTSV) no son inimaginables circunstancias que afecten a la voluntariedad por error, coacción o amenaza33.

El art. 80 LTSV determina igualmente que lo que tiene eficacia terminadora del procedimiento es el pago del 50 por 100 de la multa prevista para la infracción imputada. Si en la notificación de la denuncia se ha hecho mal el cálculo y para una multa

32 Así (interpretando preceptos distintos a los de la nueva regulación del pago voluntario en cuantía reducida) Huergo, Los contratos..., p. 425: “la interposición del recurso procedente, a que se refiere el RPPS, debe entenderse que alude a la impugnación de la resolución sancionadora por vicios en el consentimiento del particular, por incompetencia del órgano, por defectos en la notificación, etc., pero sin que quepa el replanteamiento fáctico o jurídico del fondo de la cuestión, es decir, la existencia de la infracción y la corrección de la sanción impuesta". También Lozano, La extinción..., p. 123: "la restricción del recurso ha de referirse lógicamente (...) a aquellos hechos administrativos que constituían dicho objeto. No afectará, por tanto, tal restricción a las causas de invalidez que afectan al propio acto del pago voluntario, como la falta de competencia del órgano administrativo (...) o los vicios invalidantes de la conformidad prestada".

33 Así, para el Verwarnungsgeld, que también admite esa forma de pago en el acto al Agente de la

170 autoridad, Göhler, Gesetz..., p. 412. 
de 100, por ejemplo, se ha impuesto la carga de pagar 70, en el recurso contencioso administrativo podrá pedirse la devolución de 20.

También podrán alegarse en el recurso defectos de forma: que la denuncia no se realizó en el acto, sino en un momento posterior, sin que concurrieran las circunstancias reguladas en el art. 76.2 LTSV; que no constaba en la denuncia el número de identificación profesional del Agente denunciante [art. 74.2 d) LTSV]; etc. Es evidente que la circunstancia de que esos defectos formales puedan invocarse en el recurso no significa que deban estimarse. Rige para ellos la regla general de que el defecto de forma sólo determinará la anulabilidad "cuando el acto (en este caso, la denuncia que, por disposición legal pasa de ser una imputación provisional a imputación definitiva) carezca de los requisitos formales indispensables para alcanzar su fin o dé lugar a la indefensión de los interesados" (art. 63.2 LRJPAC) ${ }^{34}$.

No podrá hacerse valer, sin embargo, el incumplimiento de requisitos formales que queden subsumidos en el ámbito de lo que delimita la aceptación de los hechos y de su calificación jurídica, excluidos del recurso. Por ejemplo, no podrá examinarse una alegación relativa a que la denuncia no consignaba la identificación del vehículo [art. 74.2 a) LTSV], porque la aceptación de los hechos y su calificación jurídica ya incluye que la infracción tuvo lugar con un vehículo por el que se debe responder.

\section{El posible escollo de la jurisprudencia constitucional sobre el derecho a la tutela judicial efectiva (art. 24.1 CE) en su vertiente de derecho al acceso a la jurisdicción}

Me parece que son sólidos los argumentos expuestos relativos a que la referencia al recurso contencioso administrativo que hace el art. 80 LTSV no obliga a aceptar que, con vulneración evidente del principio venire contra factum proprium non valet, se pueda recurrir en vía contencioso administrativa, por cualquier motivo, la sanción pagada voluntariamente en cuantía reducida. $\mathrm{Y}$, sin embargo, soy consciente de la dificultad que tendría un órgano judicial para inadmitir un recurso contencioso administrativo en el que se cuestionaran los hechos o la calificación jurídica, dado que no existe un precepto legal expreso en el que fundar la inadmisión y a la vista de la implacable jurisprudencia constitucional sobre el derecho a la tutela judicial efectiva (art. 24.1 (E) en su vertiente de derecho de acceso a la jurisdicción. En este ámbito de la denegación de una respuesta judicial sobre el fondo del asunto planteado son muy rigurosas -como es suficientemente conocido- las exigencias de la interpretación de la ley procesal favorable al principio pro actione $e^{35}$.

34 Sobre esto, por todos, Margarita Beladiez Rojo, Validez y eficacia de los actos administrativos, Madrid, 1994, pp. 132 y ss.

35 Puede verse, por ejemplo, Rafael Pérez Nieto, “Comentario al art. 24.1. Tutela judicial efectiva y jurisdicción contencioso administrativa”, en María Emilia Casas Baamonde y Miguel Rodríguez-Piñero y Bravo-Ferrer (dir.), Comentarios a la Constitución Española. XXX Aniversario, Madrid, 2009, pp. 594 y ss. 
El precepto general que primero le viene a uno a la cabeza para fundamentar la inadmisión de pretensiones procesales en la vía contencioso administrativa contrarias a los actos propios, el art. 28 LJCA, no parece aplicable al supuesto del que estamos hablando: la denuncia que pasa a convertirse en imputación definitiva por el pago voluntario de la mitad de la multa no es ni "reproducción" de un acto anterior definitivo y firme, ni un acto confirmatorio "de actos consentidos por no haber sido recurridos en tiempo y forma". Desde luego, hay un acto consentido, pero no consentido por no haber sido recurrido en tiempo y forma.

A mi juicio, no vale para fundamentar la inadmisión la simple circunstancia de que en la notificación de la denuncia la Administración ofrezca la información procesal de que, si se paga voluntariamente en cuantía reducida, no cabrá interponer el recurso contencioso administrativo ${ }^{36}$. La inadmisión judicial no puede apoyarse en un pie de recurso de la Administración, sino en una causa legal aplicada por el órgano judicial apurando las posibilidades de la interpretación pro actione.

Habrá que esperar para comprobar qué sucede en este ámbito a que el nuevo reglamento del procedimiento sancionador en materia de tráfico (que el Gobierno debe aprobar en el plazo de seis meses desde la entrada en vigor de la ley; disposición final sexta, 2, de la Ley 18/2009, de 23 de noviembre) desarrolle esta cuestión; y, en todo caso, a la práctica judicial en aplicación del art. 80 LTSV y de su eventual desarrollo reglamentario. Lo que sí parece claro es que, tras la reforma del recurso de amparo llevada a cabo por la Ley Orgánica 6/2007, de 24 de mayo, y el establecimiento del requisito de admisión de la "especial trascendencia constitucional" [art. 50.1 b) LOTC ${ }^{37}$, ya difícilmente llegará una cuestión de este tipo al Tribunal Constitucional.

\section{VALIDEZ Y EFICACIA DEL PAGO VOLUNTARIO DE LA MULTA EN CUANTÍA REDUCIDA}

\section{Un acto del imputado al que la Ley vincula la terminación del procedimiento sancionador}

El procedimiento sancionador abreviado no termina -como es regla general del procedimiento administrativo (arts. 87.1 y 89 LRJPAC)- por resolución, ni siquiera por acto presunto. La Ley dice expresamente que el procedimiento termina "sin necesidad de dictar resolución expresa" [art. 80 c) LTSV]. El art. 80 LTSV vincula la consecuencia jurídica de la terminación del procedimiento al acto del imputado consistente en pagar voluntariamente, en el acto de entrega de la denuncia o dentro del plazo de 15 días naturales, el 50 por 100 del importe de la multa prevista para la infracción de

36 Parece considerarlo suficiente, sin embargo, Lozano, "Procedimientos...", p. 246.

37 Como se sabe, el requisito de la "especial transcendencia constitucional" ha sido desarrollado (de una forma que parecería propia de un reglamento de ejecución de la Ley Orgánica del Tribunal Consti-

172 tucional) por la STC 155/2009, de 25 de junio, en especial, FJ 2. 
la que se trata. Se trata de una forma especial de terminación de un procedimiento administrativo, prevista en una ley sectorial y no en la general de procedimiento administrativo. Como ya se ha dicho, la imputación provisional de responsabilidad en que consiste el acto de la denuncia se convierte en imputación definitiva, porque así lo dispone la ley, si se paga voluntariamente la multa en cuantía reducida.

En esencia, el mismo efecto terminador del procedimiento, por disposición legal y sin resolución, que en el procedimiento abreviado se da a un acto del sancionado (el pago en plazo) lo concede la Ley también (para determinados tipos de infracciones y sanciones) a una omisión del imputado en el procedimiento sancionador ordinario: si en el plazo de los 15 días naturales siguientes a la notificación de la denuncia no se formulan alegaciones, ni se procede al pago, la imputación provisional de la denuncia se convierte en definitiva con el efecto de "acto resolutorio del procedimiento sancionador" (art. 81.5 LTSV). La redacción del precepto no debe conducir a engaño: tampoco aquí hay resolución expresa, ni acto presunto. Hay una consecuencia jurídica que la ley vincula directamente -sin mediación de actos administrativos expresos, ni ficciones de actos presuntos- a una actuación del imputado en el procedimiento. En la regulación anterior equivalente a ésta, la denuncia podía pasar a convertirse en propuesta de resolución ${ }^{38}$, pero no disponía la ley ese efecto terminador del procedimiento vinculado a la omisión de toda actuación frente a la denuncia.

Conforme a las reglas generales del procedimiento administrativo, la denuncia no inicia el procedimiento. De acuerdo con estas reglas sería lógicamente imposible que el pago de la multa fijada en una denuncia que se notificara en el acto pusiera fin a un procedimiento, que ni siquiera habría sido incoado. La iniciación de oficio del procedimiento se produce "por acuerdo del órgano competente" que, en su caso, puede deberse a la formulación de una denuncia (art. 69.1 LRJPAC).

Las cosas no son así en el procedimiento administrativo sancionador en materia de tráfico. En este ámbito "la denuncia formulada por los Agentes de la autoridad encargados del servicio de vigilancia de tráfico y notificada en el acto al denunciado constituye el acto de iniciación del procedimiento sancionador a todos los efectos" (art. 73.2 LTSV). Por eso es correcto decir que también la denuncia que se paga en el acto al Agente de la autoridad pone fin a un procedimiento sancionador ya iniciado. La regla no es nueva en el ámbito de las sanciones de tráfico. El art. 10 del Reglamento de procedimiento sancionador en materia de tráfico (aprobado por Real Decreto 320/1994, de 25 de febrero) ya disponía que en las denuncias que se notificaran en el acto había que hacer constar que "con ellas quedan incoados los correspondientes expedientes"39.

Como ya se ha dicho, frente a la sanción pagada voluntariamente en cuantía reducida no cabe recurso administrativo alguno, ni de alzada, ni el potestativo de repo-

38 Lo destaca Cano Campos, “Ordenación del tráfico...", p. 394.

39 Cano Campos, “Ordenación del tráfico...", p. 390. 
sición. La Ley quiere que la Administración no tenga que conocer nada más del asunto. Que no cabe recurso de alzada se deduce directamente del art. 80 d) LTSV: la vía administrativa ha sido agotada (en las leyes viejas se decía "causar estado") y, en consecuencia no cabe el recurso administrativo que plantea la cuestión ante el superior jerárquico (art. 114.1 LRJPAC). Que tampoco cabe el de reposición ${ }^{40}$ se deduce de la interpretación literal del art. 80 d) LTSV: la sanción es "recurrible únicamente ante el orden jurisdiccional contencioso administrativo"; y de una interpretación sistemática que compare esa redacción con la de la regulación del procedimiento sancionador ordinario del art. 81.1 y 2 LTSV. También la resolución que termina el procedimiento ordinario agota la vía administrativa y, en consecuencia, no puede ser recurrida en alzada (apartado 1), pero, a renglón seguido, se establece que "contra las resoluciones sancionadoras podrá interponerse recurso de reposición con carácter potestativo" (apartado 2).

Si la infracción por la que se impone la multa que se paga voluntariamente en cuantía reducida lleva, además, aparejada la pérdida de puntos [nuevo Anexo II ("infracciones que llevan aparejada la pérdida de puntos") de la Ley de tráfico], este efecto jurídico se produce por disposición de la ley al día siguiente de aquél en que se produzca el pago [art. 80 f) LTSV] ${ }^{41}$. Evidentemente, en la denuncia habrá debido consignarse el número de puntos cuya pérdida se vincula a la infracción imputada [art. 74.3 a) LTSV].

\section{2. ¿Reconocimiento de culpa?}

A mi juicio, en la ley no existe ni un solo indicio que permita equiparar (como se ha hecho frecuentemente con instituciones análogas) la institución del pago voluntario en cuantía reducida ni al arrepentimiento espontáneo, ni a la confesión, ni al reconocimiento de los hechos, ni a la colaboración con la justicia ${ }^{42}$. El pago voluntario de la multa en cuantía reducida es algo mucho menos subjetivo que todo eso. Por lo pronto, ni siquiera existe necesidad de una declaración expresa de aceptación o consentimiento. La aceptación está implícita en el acto material del pago. Y el consentimiento implícito en el pago se proyecta objetivamente sólo sobre la consecuencia jurídica de terminar el procedimiento sancionador de esa manera y "pasar página"43, sin discutir sobre los hechos y su calificación jurídica.

40 De la misma opinión es Cano Campos, “Ordenación del tráfico...”, p. 397.

41 Cano Campos, “Ordenación del tráfico...", p. 393.

42 Con opiniones semejantes Lozano, "Procedimientos...", p. 223; Huergo, Los contratos..., pp. 425-426: "la propia observación de lo que sucede en la práctica indica que el ciudadano que manifiesta su conformidad lo hace para obtener unos determinados efectos jurídicos, y lo hace disponiendo de los poderes de los que él es titular, es decir, de su derecho a impugnar el acto". Para la conformidad a las actas de la inspección de tributos, Arrieta, Las actas..., pp. 435-436. Para el Verwarnugsgeld alemán, también, Göhler, Gesetz..., p. 408-409.

1743 La expresión gráfica la utiliza Rafael Caballero Sánchez, Prescripción y caducidad en el ordenamiento administrativo, Madrid, 1999, p. 66, en un contexto sólo en parte análogo al del texto, el del doble 


\section{El plazo para el pago voluntario}

Para que se produzcan los efectos previstos en el art. 80 LTSV es necesario que el pago se realice "en el acto de entrega de la denuncia o dentro del plazo de 15 días naturales contados desde el día siguiente al de su notificación”. El pago realizado fuera del plazo establecido no termina el procedimiento, ni extingue la responsabilidad sancionadora. Lógicamente la fecha que debe ser tenida en cuenta es la del pago por el imputado, no la del momento en que se pone efectivamente ese pago en conocimiento de la Administración.

Ningún problema parece existir en que el imputado solicite una ampliación del plazo en los términos del art. 49.1 LRJPAC, con la alegación, por ejemplo, de una dificultad económica momentánea. La solicitud de la ampliación ha de hacerse, sin embargo, antes de que haya expirado el plazo. "En ningún caso podrá ser objeto de ampliación un plazo ya vencido" (art. 49.3 LRJPAC).

Legalmente, pues, la Administración no puede aceptar, para dar efectos de terminación del procedimiento abreviado, un pago realizado fuera del plazo. No obstante, como las multas pueden ser abonadas en cualquier momento del procedimiento ordinario (art. 90.1 LTSV), puede tenerse el pago en cuantía reducida realizado fuera de plazo como pago a cuenta de la multa que finalmente fuera impuesta. Si, finalmente, en el procedimiento ordinario no se impusiera multa alguna, el abono efectuado deberá calificarse como pago (y cobro) de lo indebido.

\section{Revisión y revocación de la multa pagada voluntariamente en cuantía reducida}

La sanción pagada en cuantía reducida, como acto de gravamen, puede ser -a mi juicio- revisada de oficio (y la cuantía de la multa abonada devuelta a quien la pagó) si la Administración constata en ella vicios de legalidad. No creo que el efecto de la “firmeza de la sanción" que el art. 80 f) LTSV vincula al pago voluntario en cuantía reducida llegue tan lejos como para impedir a la Administración el ejercicio de esa facultad de revisión. La revisión estará sometida a los límites generales establecidos en el art. 106 LRJPAC.

Es evidente, sin embargo, que la eventual declaración de invalidez (por esta vía de la revisión) de la sanción pagada voluntariamente no permite a la Administración continuar con el procedimiento ordinario para sancionar por los hechos que dieron lugar a dicha sanción. A estos efectos la sanción sí es firme e inmodificable [art. 80 f) LTSV]. Ya se ha dicho que uno de los elementos característicos de la institución que

fundamento de la caducidad y la prescripción: el principio de seguridad jurídica y la necesidad de pasar página como garantía de la eficacia. 
nos ocupa es precisamente la de prohibir a la Administración dirigirse de nuevo, en otro procedimiento, contra el imputado para exigir responsabilidad sancionadora por aquellos hechos.

Por razones de oportunidad no parece posible revocar la sanción pagada voluntariamente en cuantía reducida (al amparo de lo dispuesto en el art. 105.1 LRJPAC). Coincido con quienes piensan que esto sólo sería posible en los casos en que expresamente el ordenamiento lo permitiera, pues, de otra manera, la revocación de la sanción habría de calificarse como "dispensa o exención no permitida por las leyes" (uno de los límites a los que somete el precepto citado el ejercicio de esa competencia administrativa) $)^{44}$.

\section{PAGO VOLUNTARIO Y NON BIS IN IDEM}

\section{La prohibición absoluta de la doble sanción administrativa por los mismos hechos y con el mismo fundamento}

Como ya se ha dicho en varias ocasiones, el efecto de la "firmeza de la sanción (... ) desde el momento del pago" [art. 80 f) LTSV] impide a la Administración tramitar un nuevo procedimiento sancionador para exigir al infractor responsabilidad de esa naturaleza por los mismos hechos. La Administración se encuentra, tras el pago voluntario de la multa en cuantía reducida, con un impedimento en el plano procedimental; $y$, en el sustantivo, la responsabilidad del sancionador ya ha sido extinguida. Una eventual tramitación de un nuevo procedimiento sancionador con el resultado de imposición de otra sanción administrativa vulneraría -a mi juicio- no sólo el citado art. 80 f) LTSV, sino, también, la prohibición del non bis in idem contenida, como derecho fundamental, en el art. 25.1 CE ${ }^{45}$.

44 Así, por ejemplo, Alfredo Gallego Anabitarte y Ángel Menéndez Rexach (dir.), Acto y procedimiento administrativo, Madrid - Barcelona, 2001, p. 292. Ésta parece ser también la opinión de Nieto, Derecho administrativo..., p. 132: "la revocación es admisible si se constata que la sanción fue indebidamente impuesta; no siendo admisible, en cambio, si su imposición fue correcta”. Para Ínigo Sanz Rubiales, "Revocación de sanciones administrativas por motivos de oportunidad”, RAP, núm. 148 (1999), pp. 359 y ss., "aunque el ordenamiento español reconoce en abstracto la revocabilidad de las sanciones", en la aplicación concreta de esta facultad la Administración se encuentra con "intensas limitaciones que restringen en gran medida la posibilidad de su ejercicio" (p. 385).

45 Coincido con Nieto, Derecho administrativo..., p. 219, en que "la prohibición del bis in idem en modo alguno se encuentra constitucionalmente positivizada", salvo -añado yo- porque el Tribunal Constitucional ha dicho que sí lo está en el art. 25.1 CE. La conexión entre el texto literal de ese precepto y la idea contenida en el non bis in idem sólo puede llevarse a cabo mediante un delicado esfuerzo argumentativo. El más logrado es, a mi juicio, el siguiente: "la garantía material de no ser sometido a bis in idem sancionador, que (...) está vinculada a los principios de tipicidad y legalidad de las infracciones, tiene como finalidad evitar una reacción punitiva desproporcionada, en cuanto dicho exceso punitivo hace quebrar la garantía del ciudadano de previsibilidad de las sanciones, pues la suma de la pluralidad de sanciones crea una san-

176 ción ajena al juicio de proporcionalidad realizado por el legislador y materializa 


\section{Pago voluntario en cuantía reducida y posterior proceso penal}

El ámbito de las infracciones a las que es aplicable el procedimiento sancionador abreviado es muy amplio. El art. 79.2 LTSV sólo prevé que dicho procedimiento no sea de aplicación a las siguientes infracciones: conducir vehículos que tenga instalados inhibidores de radar u otros mecanismos con la misma finalidad [art. $65.5 \mathrm{~h}$ ) LTSV]; el incumplimiento por el titular o el arrendatario del vehículo de la obligación de identificación del conductor responsable de la infracción [art. 65.5 j) LTSV]; y todas las infracciones muy graves (realización en la vía pública de obras sin autorización, incumplimiento de normas sobre autorización y funcionamiento de las autoescuelas, etc.) del art. 65.6 LTSV. No es difícil caer en la cuenta de que ese amplio ámbito de conductas tipificadas como infracción administrativa puede solaparse con conductas tipificadas por la ley penal. El legislador es consciente de esta circunstancia: "son infracciones muy graves, cuando no sean constitutivas de delito, las siguientes conductas (... )" (art. 65.5 LTSV).

La forma expeditiva de terminar el procedimiento abreviado en que consiste el pago de la multa en cuantía reducida puede hacer de difícil aplicación en estos casos la regla prevista en el art. 72 LTSV con el objeto doble de evitar la doble sanción administrativa y penal, por un lado, y de garantizar, por otro, la preferencia de la jurisdicción penal en el ejercicio del ius puniendi del Estado: cuando el hecho ofrezca apariencia de delito o falta perseguible de oficio, la Autoridad administrativa lo pondrá en conocimiento del Ministerio Fiscal y acordará la suspensión de las actuaciones. En el supuesto, por ejemplo, de una denuncia notificada en el acto y pagada inmediatamente al Agente denunciante no es fácil siquiera que se den las circunstancias adecuadas para que pueda aplicarse con la reflexión suficiente la técnica normativa de articulación de las dos vías sancionadoras ${ }^{46}$.

Es sabido que en la STC 177/1999, de 11 de octubre, el Tribunal Constitucional, en un supuesto en el que por unos mismos hechos se había impuesto, primero, una sanción administrativa y, después, una condena penal, consideró vulnerada la prohibición constitucional del bis in idem (art. 25.1 CE), estimó el recurso de amparo interpuesto y anuló la sanción penal impuesta ${ }^{47}$. Con posterioridad, la STC 2/2003, de 16 de enero, rectificó formalmente (art. 13 LOTC) la doctrina constitucional anterior. En síntesis, puede decirse que esta nueva doctrina, por una parte, persigue garantizar en todo caso la preferencia sancionadora de la jurisdicción penal (si hay doble sanción, penal y administrativa, no siempre es nula la segunda sanción -aunque esta fuera la penal-, sino que siempre es nula, precisamente, la administrativa ${ }^{48} ; \mathrm{y}$, por otra, hizo

46 Así Cano Campos, “Ordenación del tráfico...", p. 393.

47 Sobre los problemas de fondo que suscita el criterio de esa sentencia de anular la sanción formalmente impuesta en segundo lugar puede verse Mercedes Pérez Manzano, La prohibición constitucional de incurrir en bis in idem, Valencia, 2002, en especial, pp. 61 y ss.

48 Discrepo, por eso, de Cano Campos, “Ordenación del tráfico...", p. 393, para quien "al incentivo del 50 por 100 de reducción de la multa, habrá que añadir la eventualidad de soslayar una sanción penal”. 
"más material" la vertiente material(si se me permite la expresión) del non bis in idem: no basta para considerar vulnerada la prohibición constitucional de que se trata con que formalmente existan dos decisiones sancionadoras, sino que es necesario que exista reiteración punitiva material: si en la sentencia penal "se descuenta" la multa administrativa, no hay bis in idem.

La prohibición constitucional del bis in idem tiene -como se sabe- dos vertientes. La primera es la formal o procedimental: el ciudadano no puede ser sometido a dos procesos penales por los mismos hechos (y con el mismo fundamento). Pero, "en ciertos casos la substanciación de un procedimiento administrativo sancionador y un proceso penal (...) puede ocasionar (también) la vulneración del derecho a no ser sometido a un doble proceso" (STC 2/2003, de 16 de enero, FJ 8). Que eso sea así depende de la complejidad del procedimiento administrativo y de la naturaleza y magnitud de la sanción que sea posible imponer en él (STC 2/2003, FJ 8). Si esa complejidad, naturaleza y magnitud pudieran equipararse a las propias de un proceso penal se produciría la vulneración de la vertiente formal o procedimental de la prohibición constitucional del bis in idem.

Ya se ha dicho que el procedimiento sancionador abreviado en materia de tráfico, más que un tipo de procedimiento con trámites simplificados, es propiamente una forma automática de considerar el procedimiento terminado. Por eso, es difícil aceptar que el pago voluntario de una multa en cuantía reducida seguido de la tramitación posterior de un proceso penal por los mismos hechos y con el mismo fundamento pueda incurrir en vulneración de esta vertiente de la prohibición constitucional considerada.

La segunda vertiente del non bis in idem es la material o sustantiva: por unos mismos hechos no pueden imponerse (con el mismo fundamento) dos sanciones, en lo que ahora nos interesa, una primera administrativa (pagada voluntariamente en cuantía reducida) y, después, una penal [STC 2/2003, FJ 3 a)]. No obstante, si las sanciones son homogéneas (multas pecuniarias, por ejemplo), no se vulnera en non bis in idem si en la condena penal posterior se descuenta la cuantía de lo que se pagó por la sanción administrativa, porque -como ya se ha dicho- el art. 25.1 CE "no prohíbe el doble reproche aflictivo, sino la reiteración sancionadora de los mismos hechos con el mismo fundamento padecida por el mismo sujeto" (STC 2/2003, FJ 6).

Ahora bien, de la circunstancia de que la sentencia penal condenatoria que descuenta la multa administrativa ya pagada no sea contraria al art. 25.1 CE no puede -a mi juicio- deducirse que ésa sea la mejor manera de articular técnicamente el ejercicio de la competencia administrativa sancionadora y el de la jurisdicción penal. La técnica del "descuento" es sólo una salida posible debida al "hecho de que la legisla-

Creo que lo que dejó claro la STC 2/2003 es, precisamente, la preferencia del ejercicio del ius puniendi por 178 la jurisdicción penal y que, en consecuencia, la presa jurisdicción al órgano judicial penal. 
ción no (prevé) expresamente solución para los casos en los que la Administración no suspenda el expediente administrativo, estando un procedimiento penal abierto (...). Sólo al legislador corresponde establecer los mecanismos normativos de articulación del ejercicio de la potestad punitiva de la Administración y por la jurisdicción penal para evitar la reiteración sancionadora y contemplar las consecuencias que deriven de su incumplimiento" (STC 2/2003, FJ 6).

En mi opinión, una adecuada solución técnica sería la de que, antes de dictar su sentencia condenatoria, el órgano judicial requiriera a la Administración para que procediera a revisar la sanción pagada voluntariamente, para dejarla sin efecto, según lo que se ha dicho más arriba. Debe tenerse presente que la sanción es en este caso nula de pleno Derecho, porque la norma sancionadora administrativa no es aplicable cuando pueda ser aplicable la sanción penal; y la Administración pierde su competencia sancionadora -pasa a ser manifiestamente incompetente [art. 62.1 b) LRJPAC]- cuando la puede tener la jurisdicción penal ( vid. STC 2/2003, FJ 9). El hecho es que cuando se va a dictar la sentencia condenatoria penal se pone de manifiesto que la norma penal era efectivamente aplicable y que la Administración no tenía, en consecuencia, la competencia sancionadora.

Con más motivo deberá hacerse uso de esta técnica -previo requerimiento por parte del órgano judicial a la Administración para que revise la sanción voluntariamente pagada en cuantía reducida antes de que sea dictada la sentencia condenatoria- en el caso de que la sanción administrativa y la sanción penal sean de naturaleza heterogénea (por ejemplo, pérdida de puntos y privación del derecho a conducir) y, por tanto, no pueda llevarse a cabo el descuento de la sanción administrativa en la condena penal.

\section{BIBLIOGRAFÍA CITADA}

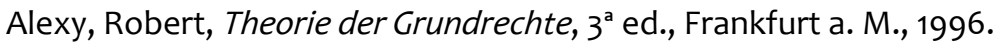

Arrieta Martínez de Pisón, Juan, Las actas de la inspección de los tributos, Madrid, 1994.

Barona Vilar, Silvia, La conformidad en el proceso penal, Valencia, 1994.

Beladiez Rojo, Margarita, Validez y eficacia de los actos administrativos, Madrid, 1994.

Boujong, Karlheinz (coord.), Karlsruher Kommnentar zum Gesetz über Ordnungswidrigkeiten, Múnich, 1989.

Butrón Baliña, Pedro M., La conformidad del acusado en el proceso penal, Madrid, 1997.

Caballero Sánchez, Rafael, Prescripción y caducidad en el ordenamiento administrativo, Madrid, 1999.

Canaris, Claus-Wilhelm, El sistema en la Jurisprudencia, trad. esp. de la $2^{\mathrm{a}}$ ed. alemana (Systemdenken und Systembegriff in der Jurisprudenz) de 1983, Madrid, 1998.

Cano Campos, Tomás, “Ordenación del tráfico de vehículos y personas", Anuario de Derecho Municipal, núm. 3 (2010), pp. 373 y ss. 
de Diego Díez, Luis-Alfredo, La conformidad del acusado, Valencia, 1997.

Gallego Anabitarte, Alfredo, y Menéndez Rexach, Ángel (dir.), Acto y procedimiento administrativo, Madrid - Barcelona, 2001.

Göhler, Erich, Gesetz über Ordnungswidrigkeiten, Múnich, 1995.

Huergo Lora, Alejandro, Los contratos sobre los actos y las potestades administrativas, Madrid, 1998.

- Las sanciones administrativas, Madrid, 2007.

Jiménez Campo, Javier, “Comentario al art. 10.1”, en María Emilia Casas Baamonde y Miguel Rodríguez-Piñero y Bravo-Ferrer (dir.), Comentarios a la Constitución Española. XXX Aniversario, Madrid, 2009, pp. 178 y ss.

Larenz, Karl, Metodología de la Ciencia del Derecho, trad. esp. de la $4^{\mathrm{a}}$ ed. alemana, Barcelona, 1994.

Lozano, Blanca, La extinción de las sanciones administrativas y tributarias, Madrid, 1990.

- "Procedimientos abreviados para la represión de las infracciones administrativas: el pago voluntario en cuantía reducida", REDA, núm. 66 (1990), pp. 221 y ss.

Nieto, Alejandro, Derecho administrativo sancionador, $4^{\text {a }}$ ed., Madrid, 2005.

- El arbitrio judicial, Barcelona, 2000.

Ortega Álvarez, Luis, "La coacción institucional para desistir del acceso al juez", $R A P$, núms. 100-102 (1983), pp. 1437 y ss.

Pérez Manzano, Mercedes, La prohibición constitucional de incurrir en bis in idem, Valencia, 2002.

Pérez Nieto, Rafael, "Comentario al art. 24.1. Tutela judicial efectiva y jurisdicción contencioso administrativa", en María Emilia Casas Baamonde y Miguel RodríguezPiñero y Bravo-Ferrer (dir.), Comentarios a la Constitución Española. XXX Aniversario, Madrid, 2009, pp. 594 y ss.

Prieto Álvarez, Tomás, La dignidad de la persona, Madrid, 2005.

Rebmann, Kurt, Roth, Werner, y Hermann, Siegfried, Gesetz über Ordnungswidrigkeiten. Kommentar, tomo 1, Stuttgart - Berlín - Colonia - Mainz, 1983.

Rey Martínez, Fernando, Eutanasia y derechos fundamentales, Madrid, 2008.

Rodríguez de Santiago, José María, La ponderación de bienes e intereses en el Derecho administrativo, Madrid - Barcelona, 2000.

Röhl, K. F., Allgemeine Rechtslehre, Colonia - Berlín - Bonn - Múnich, 1995.

Sanz Rubiales, Íñigo, "Revocación de sanciones administrativas por motivos de oportunidad”, RAP, núm. 148 (1999), pp. 359 y ss.

Tipke, K., Die Steuerrechtsordnung, tomo I, Colonia, 1993.

Tomás-Valiente Lanuza, Carmen, La disponibilidad de la propia vida en el Derecho penal, Madrid, 1999.

Recibido: 4 de julio de 2010

Aceptado: 26 de julio de 2010 